\title{
Разработка волоконного синтезатора частот, стабилизируемого по оптическому стандарту частоты на основе $\mathbf{Y b}^{+}$
}

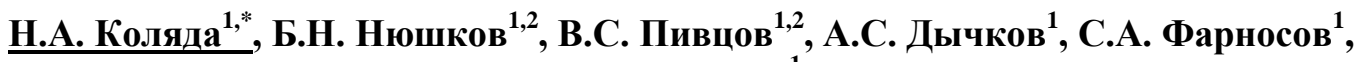 \\ В.И. Денисов ${ }^{1}$ \\ ${ }^{1}$ Институт лазерной физики СО РАН \\ ${ }^{2}$ Новосибирский государственный технический университет \\ *E-mail: n.koliada@mail.ru
}

DOI:10.31868/RFL2018.120-121

Современные потребности систем глобальной навигации, фундаментальных физических экспериментов и др. требуют метрологических характеристик на уровне $10^{-16}-10^{-17}$ для относительной частотной нестабильности опорных сигналов. Достичь таких характеристик возможно только при использовании оптических стандартов частоты. В настоящее время во всем мире активно ведутся работы по созданию оптических стандартов на холодных нейтральных атомах или ионах в ловушках. В сравнении с другими стандартами времени и частоты они могут обеспечить более высокую точность и стабильность за меньшее время измерений. Ион иттербия является оптимальным кандидатом для создания оптического стандарта частоты с возможностью бортового базирования [1]. В то же время необходимо перенести стабильность оптической частоты в радиодиапазон. Перенос реализуется с использованием фемтосекундного синтезатора частот.

Основным оптическим блоком фемтосекундного синтезатора оптических и радиочастот является фемтосекундный лазер с синхронизацией мод. Такой лазер обеспечивает стабильную генерацию гребенки эквидистантных оптических частот, при этом интервал между соседними частотами соответствует радиочастотному диапазону. Частотные параметры гребенки могут быть определены с очень высокой точностью при привязке компонент гребенки с использованием систем фазовой автоподстройки [2,3] к частоте оптического стандарта. Для создания систем космического назначения наиболее перспективно использовать волоконный синтезатор на основе волоконного фемтосекундного эрбиевого лазера. Накачка волоконного лазера осуществляется одиночными диодными лазерами, резонатор обладает малыми массой и габаритами, полный КПД может достигать несколько десятков процентов. Так же системы на основе волоконных элементов обладают высокой надежностью, они лучше защищены от воздействия внешних возмущений.

В данной работе предложены и предварительно исследованы принципы и схема стабилизации волоконного эрбиевого синтезатора частот по частоте оптического стандарта на основе одиночного $\mathrm{Yb}^{+}$. Для отработки быстрых возмущений выбран метод стабилизации с одновременным использованием внутрирезонаторного электрооптического модулятора и внерезонаторного акустооптического модулятора [4]. Частота смещения уширенной до октавы фемтосекундной гребенки детектируется с помощью f-2f интерферометра и далее стабилизируется с помощью систем автоподстройки. Компонента уширенной фемтосекундной гребенки с длиной волны 1742 нм после удвоения её частоты привязывается к выходной оптической частоте стандарта на основе одиночного $\mathrm{Yb}^{+}$. Стабилизация указанной компоненты фемтосекундной оптической гребенки и частоты смещения приводит к стабилизации всех её компонент и, таким 
образом, реализуется перенос стабильности оптического стандарта на все оптические частоты волоконного фемтосекундного эрбиевого синтезатора. Для формирования высокостабильной выходной радиочастоты, детектируются межмодовые биения разработанного волоконного синтезатора.

Работа выполнена частично в рамках проекта ИСГЗ ФАНО 0307-2016-0005 программы ФНИ СО РАН № II.11.1, номер госрегистрации АAАA-A17117030310294-3, с использованием оборудования ЦКП "Фемтосекундный лазерный комплекс".

\section{Литература}

[1] S.V. Chepurov, A.A Lugovoy et al, Journal of Physics: Conference Series, 793, 012004 (2017)

[2] Н. Беверини, М. Преведелли и др., Квантовая Электроника, 34 (6), 559-564 (2004)

[3] Б. Н. Нюшков, В. С. Пивцов и др., Квантовая Электроника, 45 (5), 486-491 (2015)

[4] Н.А. Коляда, Б.Н. Нюшков и др., Квантовая Электроника, 46 (12), 1110-1112 (2016) 